\title{
Pengaruh Internal Marketing Terhadap Inovasi, Dengan Orientasi Kewirausahaan Sebagai Variabel Mediasi
}

\author{
Dafit Ari Hardiyanto dan Hetty Karunia Tunjungsari \\ Program Studi Manajemen Fakultas Ekonomi, Universitas Tarumanagara, Jakarta \\ Email: davidarihardiyanto@gmail.com
}

\begin{abstract}
The purpose of this study was to examine the effect of internal marketing on innovation in family businesses in West Jakarta, with entrepreneurial orientation as a mediating variable. The sample used in the study is 100 actors or family business members in West Jakarta and the sampling technique uses non-probability sampling. The method of collecting data in this study with questionnaires and data was measured using a 6 level Likert scale (1-6). Data analysis using SmartPLS 3.0 program. The results of this study indicate that 1) internal marketing has a positive and significant effect on innovation, 2) internal marketing has a positive and significant effect on entrepreneurial orientation, and 3) entrepreneurial orientation has a positive and significant effect on innovation
\end{abstract}

Key Words: Internal Marketing , Innovation, Entrepreneurial orientation, Family business.

Abstrak: Tujuan dari penelitian ini adalah untuk menguji pengaruh internal marketing terhadap inovasi pada bisnis keluarga di Jakarta Barat, dengan orientasi kewirausahaan sebagai variabel mediasi. Sampel yang digunakan dalam penelitian adalah sebesar 100 pelaku atau anggota bisnis keluarga di Jakarta Barat dan teknik pengambilan sampel menggunakan non-probability sampling. Metode pengumpulan data dalam penelitian ini dengan kuisioner dan data diukur dengan menggunakan skala likert 6 tingkat (1-6). Analisis data menggunakan progam SmartPLS 3.0. Hasil penelitian ini menunjukkan bahwa 1) internal marketing berpengaruh positif dan signifikan terhadap inovasi, 2) internal marketing berpengaruh positif dan signifikan terhadap orientasi kewirausahaan, dan 3) orientasi kewirausahaan berpengaruh positif dan signifikan terhadap inovasi

Kata Kunci: Internal Marketing, Inovasi, Orientsi Kewirausahaan , Bisnis Keluarga.

\section{LATAR BELAKANG}

Pertumbuhan ekonomi suatu negara tidak lepas dari peran bisnis pada negara tersebut. Hal ini, dikarenakan laju perkembangan bisnis pada negara tersebut dapat dijadikan indikator pertumbuhan ekonomi. Semakin berkembang bisnis yang terjadi pada suatu negara maka berimbas pula pada pertumbuhan ekonomi di negara.

Berdasarkan data dari badan pusat statistik (BPS) yang dikutip pada www.bps.go.id pada bulan februari 2019, tercatat pertumbuhan perekonomian Indonesia 
pada tahun 2018 tumbuh sebesar 5,17 persen hasil ini lebih tinggi dari pertumbuhan ekonomi pada tahun 2017 sebesar 5,07 persen. Hasil tersebut menunjukkan bahwa pertumbuhan ekonomi di Indonesia dalam kondisi yang cukup baik. Salah satu yang berkontribusi akan pertumbuhan tersebut adalah perkembangan bisnis keluarga yang ada di Indonesia. Ini dikarenakan pertumbuhan ekonomi ini tidak lepas dari perkembangan bisnis keluarga yang ada di Indonesia. Hal tersebut dapat dilihat dari hasil survei Princewaterhouse coopers $(\mathrm{PwC})$ yang dikutip dari Tirto.id pada kepemilikan bisnis di indonesia ditemukan hasil bahwa 95\% bisnis di indonesia merupakan bisnis keluarga. Menurut, Meryana (2011) bisnis yang dijalankan oleh keluarga merupakan pilar utama pengerak perekonomian di wilayah asia tenggara karena mayoritas bisnis yang dijalankan di asia tenggara merupakan bisnis keluarga.

Berdasarkan survei yang dilakukan oleh Princewaterhouse Cooper (PwC) yang dikutip dari indotelko.com terhadap perkembangan bisnis keluarga didunia dengan sampel 2.800 bisnis keluarga di 50 negara pada tahun 2016. Hasil dari survei tersebut menunjukkan sebanyak $64 \%$ bisnis keluarga setahun terakhir mangalami pertumbuhan pada pelaku bisnis global. Hal ini berarti bahwa di sektor bisnis keluarga memiliki prospek yang bagus terhadap pertumbuhan bisnis baik itu dari sektor jasa maupun barang. Hal itu diperkuat dengan temuan survei $\mathrm{PwC}$ pada tahun 2016 yang dikutip dari swa.co.id terhadap pelaku bisnis keluarga di Indonesia mengenai ambisi terhadap pertumbuhan bisnisnya yang mana ditemukan hasil bahwa pelaku bisnis Indonesia sebanyak 88\% merencanakan peningkatan pertumbuhan terhadap bisnis keluarganya.

Dari survei yang dilakukan Princewaterhousse cooper(PwC) pada pelaku bisnis keluarga di Indonesia yang dilakukan melalui telfon dan kuisioner. Dari hasil survei tersebut menemukan bahwa pelaku usaha di Indonesia diprediksi akan meningkat sebanyak $73 \%$ dalam kurun waktu 5 tahun kedepan dan perlunya untuk terus berinovasi sebanyak $76 \%$. Hal tersebut dikarenakan semakin banyaknya pelaku usaha maka, Menuntut perusahaan atau pelaku bisnis harus melakukan inovasi baik produk maupun jasa. Hal ini, memaksa pelaku usaha untuk melakukan praktik-praktik dalam mengembangkan dan menciptakan jasa atau produk yang baru guna memenuhi kebutuhan konsumen dan agar mampu bersaing dengan kompetitor.

Dengan melakukan pembaharuan atau inovasi terhadap produk maupun jasa yang dihasilkan. Maka, akan menjadikan siklus hidup perusahaan dapat bertahan dari ancaman kompetitor yang lebih kompetitif. Namun, dalam menciptakan suatu gagasan baru atau ide baru terhadap produk maupun jasa dapat dipengaruhi berbagai faktor. Faktor tersebut dapat berupa dari dalam atau internal dan faktor dari luar atau eksternal perusahaan dalam menciptakan inovasi produk maupun jasa. Dalam beberapa tahun terakhir inovasi dijadikan faktor penting dalam organisasi atau perusahaan dengan tujuan untuk memperoleh keuntungan, mempertahankan, mengembangkan, dan mempunyai daya saing dengan kompetitor (Chen \& Lin, 2013). Menurut Craig dan Moores (2006) dalam penelitiannya menemukan berbagai faktor yang dapat mempengaruhi inovasi di dalam bisnis keluarga antara lain internal marketing dan orientasi kewirausahaan.

Salah satu faktor internal yang dapat mempengaruhi adalah internal marketing atau pemasaran internal. Pemasaran internal atau internal marketing merupakan tindakan atau perlakuan yang dilakukan oleh perusahaan dengan menjadiakan karyawan sebagai pelanggan utama didalam perusahaan (Elsamen \& Alsrudin, 2012). Dengan adanya pelayanan internal yang baik terhadap karyawan diyakini dapat meningkatkan rasa 
sukarela karyawan dalam menyampaikan ide dan gagasan baru terhadap pembaharuan produk maupun jasa yang dihasilkan oleh perusahaan. Konsep tersebut sesuai dengan pendapat (Rosenbluth \& Peter dalam Kotler \& Keller, 2009) bahwa penerapan internal marketing untuk memuaskan konsumen eksternal maka harus memuaskan konsumen internalnya yaitu karyawan pada perusahaan atau organisasi

Orientasi kewirausahaan mencerminkan sejauh mana organisasi dapat berkembang melalui tindakan inovasi, berani mengambil resiko untuk memasuki pasar yang baru dan layanan baru secara proaktif mencari peluang baru serta bergerak lebih cepat dari kompetitor dalam memanfaatkan peluang yang ada (Soininen dkk.,2012). Organisasi yang memiliki orientasi kewirausahaan kuat akan cenderung lebih memiliki gagasan dalam mengalokasikan sumber daya yang ada guna menciptakan inovasi (Bai dan Ren, 2016). Selain itu, dengan adanya orientasi kewirausahaan yang kuat maka akan menjadikan organisasi atau perusahaan tersebut akan memiliki keunggulan yang kompetitif dipasar (Slater dan Nerver, 1995). Penerapan orientasi kewirausahaan akan menjadikan perusahaan lebih terbuka terhadap perubahan dan ide baru yang berarti akan meningkatkan pengetahuan yang lebih besar yang berguna untuk pembaharuan produk, pengembangan produk dan akhirnya tercapinya inovasi (Shu dkk.,2015).

\section{KAJIAN TEORI}

Inovasi. di artikan sebagai kecenderungan perusahaan untuk mempromosikan dan mendukung tindakan dalam hal ide, eksperimen, dan proses kreatif yang mengarah pada peluang baru untuk mendapatkan dan mempertahankan keunggulan kompetitif, baik dalam hal produk maupun teknologi yang ada di pasar (Miller, 1983).

Orientasi Kewirausahaan. adalah perilaku untuk mengambil resiko yang terkait dengan kegiataan bisnis, mendukung perilaku perubahan, dan bersaing secara agresif dengan perusahaan lain (Covin dkk., 2006) . Terdapat beberapa pendapat para ahli mengenai definisi orientasi kewriausahaan.

Internal Marketing. merupakan upaya terencana menggunakan pendekatan untuk mengatasi resistensi organisasi terhadap perubahan dan untuk menyelarasakan, memotivasi, dan mengkoordinasi karyawan ke arah yang efektif dan fungsional untuk memberikan kepuasan pelanggan melalui proses menciptakan karyawan yang termotivasi dan berorientasi pelangan (Rafiq \& Ahmed, 2000).

Kaitan Internal Marketing Terhadap Inovasi. Pemasaran internal dapat diterapkan didalam perusahaan sebagai alat pemasaran untuk karyawannya didalam perusahaan (Piercy, 1995). Internal marketing dapat menumbuhkan kesadaran antar karyawan agar terciptanya rasa akan pentingnya komunikasi antar sesama anggota yang diperlukan didalam perusahaan (Ling, 2004). Dengan adanya komunikasi internal yang baik akan menumbuhkan rasa sukarela dalam menyampaikan ide-ide atau gagasan yang bertujuan untuk mengembangkan perusahaan. 
Zampetakis dan Moustakis (2007) berpendapat bahwa internal marketing sangat penting untuk merangsang manajemen organisasi perusahaan yang pada akhirnya akan terbentuk budaya inovatif dan pengembangan inovasi didalam perusahaan

H1: Terdapat hubungan positif dan signifikan antara internal marketing terhadap inovasi

Kaitan internal marketing terhadap orientasi kewirausahaan. Penerapan internal marketing dapat mendororng terciptanya hubungan kerjasama informal antar sesama anggota karyawan di dalam perusahaan.Dari penerapan internal marketing yang terjalin diharapkan dapat meningkatkan kinerja karyawan sehingga terciptalah inovasi (Hayton, 2005). Menurut Rafiq dan Ahmed (1993) internal marketing dapat diaplikasikan atau dipraktekkan dalam bisnis keluarga untuk mendorong sikap orientasi kewirausahaan pada karyawan didalam perusahaan. Hal tersebut mengindikasikan bahwa internal marketing dapat mempengaruhi motivasi karyawan dalam menciptakan gagasan baru, berekerja secara proaktif dan berani mengambil resiko.

H2 : Terdapat hubungan positif dan signifikan antara internal marketing terhadap orientasai kewirausahaan.

Kaitan orientasi kewirausahaan terhadap inovasi. Dalam menciptakan perusahaan yang kompetitif memerlukan adanya pembaharuan ide, gagasan, dan konsep produk baru hal tersebut sama seperti konsep dari inovasi (Madhousi dkk., 2011). Banker dan Sinkula (2009) melakukan penelitian orientasi kewirausahaan pada inovasi yang hasilnya berpengaruh sigifikan terhadap inovasi. Perusahaan dengan orientasi yang kuat akan memiiki kemampuan yang lebih baik dalam hal untuk mengubah lingkungan dengan tidakpastian menjadi peluang yang berguna bagi perusahaan. Orientasi kewirausahaan memiliki 3 dimensi menurut (Patrick \& Justin, 2010) Yaitu inovasi, proaktif, dan mengambil resiko.

H3 : Terdapat hubungan positif dan signifikan antara orientasi kewirausahaan terhadap inovasi

Kerangka pemikiran dalam penelitian ini, dapat digambarkan sebagai berikut:

Gambar. 1 Kerangka Pemikiran

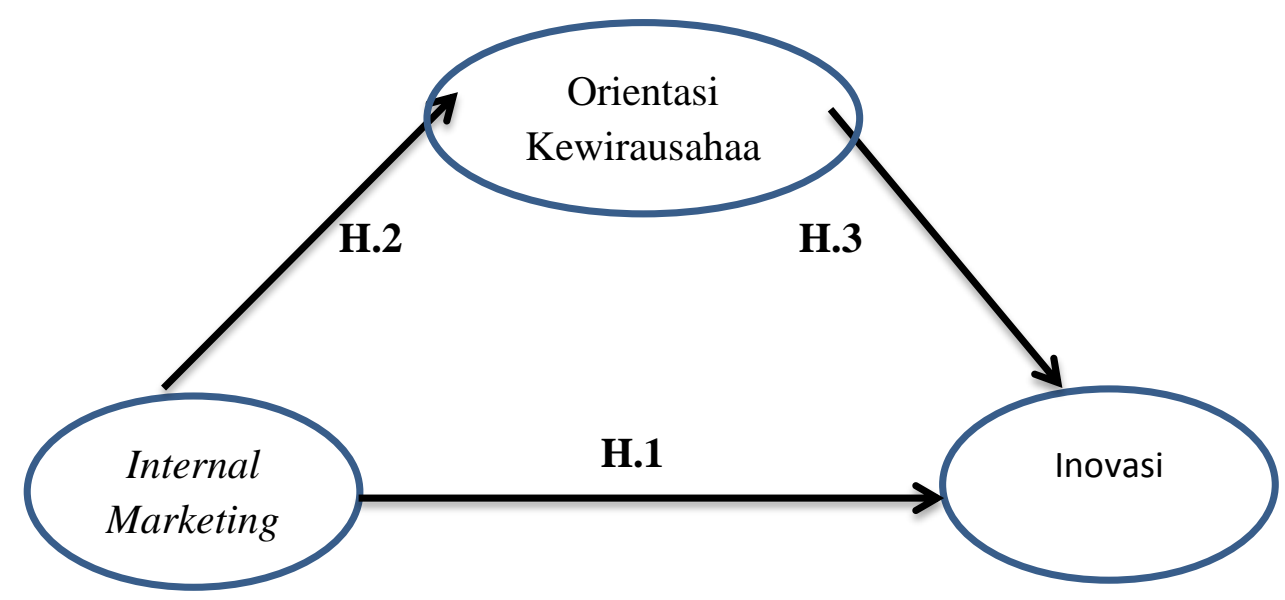




\section{METODOLOGI}

Menurut Sekaran dan Bougie (2013:270) populasi adalah keseluruhan kelompok orang, kejadian atau hal-hal yang diselidiki oleh peneliti pada suatu wilayah atau tempat. Sedangkan menurut Aritonang (1998:101) Populasi diartikan sebagai subjek yang menjadi unsur untuk diteliti yang diambil secara keseluruhan pada suatu tempat atau wilayah. Populasi yang dijadikan oleh peneliti yaitu pelaku bisnis keluarga yang ada di jakarta barat

Dalam penelitian ini, pemilihan sampel menggunakan metode non probabability sampling. Menurut Sekaran dan Bougie (2013:252) non probability sampling merupakan pemilihan sampel yang mewakili populasi yang dijadikan responden dimana setiap anggota dari populasi tidak memiliki kesempatan yang sama untuk dipilih sebagai responden.

Operasional Variabel. Pada penelitian ini, variabel yang digunakan terdiri atas variabel independen (variabel bebas), variabel mediasi, dan variabel dependen (variabel terikaat). Variabel Independen yang digunakan dalam penelitian ini adalah internal mareting,

variabel mediasi adalah orientasi kewirausahaan, dan variabel dependen yang digunakan dalam penelitian ini adalah inovasi.

Hasil Uji Validitas. pengujian validitas dapat dilakukan dengan covergent validity dan discriminant validity. Convergent validity pada penelitian ini mengunakan aturan praktis dengan melihat nilai dari averange variance validity(AVE). Variabel dapat dikatakan valid apabila nilai setiap variabel lebih besar dari 0,50 (Bagozzi dan Yi, 1998). Berikut uji covergent validity

Tabel 1 . Hasil Uji AVE

\begin{tabular}{|c|c|c|}
\hline Variabel & $\begin{array}{c}\text { Averange variance } \\
\text { extracted(AVE) }\end{array}$ & Keterangan \\
\hline Inovasi & 0,561 & Valid \\
\hline Internal marketing & 0,573 & Valid \\
\hline Orientasi kewirausahaan & 0,595 & Valid \\
\hline
\end{tabular}

Dari data diatas maka diperoleh nilai averange variance axtracted pada masingmasing variabel yaitu inovasi 0,561 , internal marketing 0,573 , dan orientasi kewirausahaan 0,590 maka masing-masing variabel tersebut telah memenuhi syarat validitas dengan nilai AVE lebih dari 0,5.

Hasil Uji Reliabilitas. Menurut Ghozali (2006) analisis reliabilitas adalah alat yang digunakan untuk mengukur suatu kuisioner yang merupakan indikator dari variabel. Hal tersebut dapat di ukur melalui jawaban seseorang terhadap pernyataaan pada kuisioner menjawab dengan konsisten dari waktu kewaktu. Dalam menguji reliabilitas terdapat 2 metode pengujian yaitu dengan cronbach's alpha dan composite reliability

Menurut Ghozali (2011:48) suatu variabel dapat dikatakan reliabel apabila nilai Cronbach's Alpha $\geq 0,60$, maka istrumen tersebut memiliki nilai reliabilitas yang mencukupi. Dan pada Nilai composite reliability dikatakan reliabilitas apabila lebih besar dari 0,7 (Hair dkk., 2011).Nilai analisis reliabilitas pada tabel 2 sebagai berikut: 
Tabel 2. Hasil Uji Reliabilitas

\begin{tabular}{|c|c|c|}
\hline Variabel & Cronbach's Alpha & Composit Reliability \\
\hline Inovasi & 0,609 & 0,793 \\
\hline Internal marketing & 0,628 & 0,801 \\
\hline Orientasi Kewirausahaan & 0,659 & 0,815 \\
\hline
\end{tabular}

Berdasarkan tabel 2 diatas, dapat diketahui bahwa nilai cronbach alpha pada penelitian ini memiliki nilai diatas 0,6. Inovasi memiliki nilai cronbach's aplha sebesar 0,609 , internal marketing sebesar 0,628, dan orientasi kewirausahaan sebesar 0,659 maka masing-masing variabel pada pengujian cronbach's alpha memenuhi kriteria karena nilai pada masing-masing variabel lebih dari 0,6. Selanjutnya pada composite reliability juga memiliki nilai diatas 0,7 yaitu Inovasi 0,793 , internal marketing 0,801 , dan orientasi kewirausahaan 0,815 . Berdasarkan nilai tersebut, maka pada data pada penelitian ini reliabel karena masing-masing variabel telah memenuhi kriteria Cronbach's alpha dan Composite reliability.

Hasil Uji Koefisien Determinasi. Uji koefisien determinasi atau $\mathrm{R}^{2}$ dalam penelitian ini dapat digunakan sebagai guna untuk melihat seberapa besar perubahan pada variabel dependen yaitu inovasi yang akan dijelaskan oleh variabel independen yaitu internal marketing, orientasi kewirasuahaan dan sisa dapat dijelaskan oleh faktor lain.

Tabel 3. Uji Koefisien Determinasi

\begin{tabular}{|l|l|}
\hline & R square \\
\hline Inovasi & 0,603 \\
\hline Orientasi kewirausahaan & 0,388 \\
\hline
\end{tabular}

Dari tabel 3 diatas dapat dilihat nilai $\mathrm{R}$ square yang diperoleh yaitu:

1) Nilai $R$ square pada variabel inovasi sebesar 0,603 hal ini berarti bahwa sebesar $60,3 \%$ variabel dependen (Y) dalam penelitian ini yaitu inovasi. Dengan ini, maka dapat disimpulkan inovasi dapat dijelaskan oleh variabel Orientasi kewirausahaan dan internal marketing. Sisanya sebesar 39,7\% dijelaskan variabel lain diluar struktur pada penelitian ini.

2) Nilai R square pada variabel orientasi kewirausahaan sebesar 0,388 . Hal ini berarti orientasi kewirausahaan dapat dijelaskan oleh variabel internal marketing sebesar $38,8 \%$ dan sisanya sebesar $61,2 \% \quad(100 \%-38,8 \%)$ dijelaskan pada variabel diluar penelitian ini.

Hasil Uji Hipotesis. Pengujian ini bertujuan untuk menguji hipotesis yang ada dalam penelitian ini dan untuk mengetahui hubungan atau keterkaitan antar variabel yang terdapat pada penelitian ini antara variabel satu dengan variabel lainnya. Dengan smartPLS uji hipotesis dapat melihat nilai P-value dan T-statistic. Dengan nilai cut off P-value 0,05 dan T-statistic 1,96. Berikut hasil uji hipotesis dapat dilihat pada tabel 5. 
Tabel 5. Hasil Uji Bootsrapping

\begin{tabular}{|c|c|c|c|}
\hline Variabel & T-statistics & P-values & Path Coefficient \\
\hline $\begin{array}{c}\text { Internal marketing -> } \\
\text { inovasi }\end{array}$ & 2,861 & 0,004 & 0,269 \\
\hline $\begin{array}{c}\text { Internal marketing -> } \\
\text { orientasi kewirausahaan }\end{array}$ & 8,372 & 0,000 & 0,627 \\
\hline $\begin{array}{c}\text { Orientasi kewirausahaan } \\
\text {-> inovasi }\end{array}$ & 6,903 & 0,000 & 0,584 \\
\hline
\end{tabular}

Berdasarkan hasil tabel 5 diatas, maka dapat dilihat nilai $t$-ststistic pada variabel internal marketing terhadap inovasi sebesar 2,861 dan hasil ini lebih besar dari nilai cut off yang telah ditetapkan yaitu sebesar 1,96 dan nilai p-value sebesar 0,004 hasil tersebut lebih kecil dari nilai cut off yang telah ditetapkan yaitu sebesar 0,05 . Dengan hasil tersebut maka dapat disimpulkan bahwa HO ditolak dan $\mathrm{H} 1$ diterima yang berarti: Ada hubungan yang positif dan signifikan antara internal marketing dengan inovasi pada bisnis keluarga.

Berdasarkan tabel 5 diatas, maka dapat dilihat nilai $t$-statistic pada variabel internal marketing terhadap orientasi kewirausahaan sebesar 8,372 nilai tersebut lebih besar dari nilai cut off yang telah ditetapkan yaitu sebesar 1,96 dan nilai p-value sebesar 0,000 dan nilai tersebut lebih kecil dari nilai cut off yang telah ditetapkan oleh yaitu sebesar 0,05 dengan hasil tersebut maka dapat disimpulkan bahwa $\mathrm{HO}$ ditolak dan $\mathrm{H} 2$ diterima yang berarti Ada hubungan yang positif dan signifikan antara internal marketing terhadap orientasi kewirausahaan pada bisnis keluarga.

Berdasarkan tabel 5 diatas dapat dilihat nilai t-statistic pada variabel orientasi kewirausahaan terhadap inovasi sebesar 6,903 nilai tersebut lebih besar dari nilai cut off yang telah ditetapkan yaitu sebesar 1,96 dan nilai p-value sebesar 0,000 nilai ini lebih kecil dari nilai cut off yang telah ditetapkan yaitu sebesat 0,05 dengan hasil tersebut maka dapat disimpulkan bahwa $\mathrm{HO}$ ditolak dan $\mathrm{H} 3$ diterima yang berarti bahwa Ada hubungan yang positif dan signifikan antara orientasi kewirausahaan terhadap inovasi pada bisnis keluarga.

\section{DISKUSI}

Analisis validitas dan reliabilitas yang telah di bahas pada bab 3 sebelumnya menunjukkan setiap variabel valid. Pada analisis validitas yang dikur melalui averange variance extacted (AVE) menunjuukan semua variabel meimiliki angka diatas 0,5 dan loading factor pada masing-masing variabel lebih dari 0,7 .

Hasil pengujian pada hipotesis pertama menunjukkan bahwa internal marketing berhubungan positif dan signifikan terhadap inovasi pada bisnis keluarga. Hal ini menunjukkan bahwa hipotesis tersebut konsisten dengan penelitian sebelumnya yang telah dilakukan oleh (Jalilvand dkk.,2017; Rafeei dan Rafeei, 2014; Ruizalba dkk., 2014; Murray dkk.,2011). 
Hasil penelitian yang dilakukan oleh Kocak dkk. (2016) juga menemukan bahwa internal marketing berhubungan positif terhadap inovasi. Oleh karena itu, dapat disimpulkan bahwa dengan adanya penerapan internal marketing didalam organisasi bisnis atau perusahaan diyakini dapat meningkatkan sikap sukarela karyawan terhadap perusahaan melalui ide-ide baru yang dapat membantu memperkembangkan dan menjadikan perusahaan yang berkompetitif dipasar. Karyawan berperan penting terhadap segala aktifitas penting didalam perusahaan serta karyawan merupakan sumber utama pembentuk inovasi didalam perusahaan (Hotho \& Champion, 2011). Penerapan internal marketing dapat di implikasikan perusahaan melalui pelatihan dan motivasi terhadap karyawan. Melalui pelatihan tersebut dapat meningkatkan sumber daya manusia didalam perusahaan sehingga terciptalah inovasi atau gagasan-gagasan baru ( Bommer \& Jalajas, 2002)

Hasil pengujian untuk hipotesis kedua menunjukkan internal marketing berhubungan positif dan signifikan terhadap orientasi kewirausahaan pada bisnis keluarga. Hasil ini menunjukkan bahwa hipotesis tersebut konsisten dengan penelitian sebelumnya yang dilakukaan oleh ( Jalilvand dkk., 2017; Fang dkk., 2014; Hayton, 2005; Ivancevich dan Gilbert., 2000) yang menemukan hasil bahwa internal marketing berpengaruh positif dan signifikan.hal ini dapat disimpulkan bahwa penerapan internal marketing didalam perusahaan dapat menignkatkan sikap proaktif,inovatif dan berani mengambil resiko. Hasil penelitian ini berbanding lurus dengan Teori dari (Rafiq \& Ahmed, 1993) didalam teori tersebut menyatakan bahwa internal marketing dapat di aplikasikan atau dipraktikan didalam bisnis keluarga guna mendorong sikap orientasi pada karyawan didalam menjalankan bisnis tersebut.

Hasil pengujian untuk hipotesis ketiga menunjukkan orientasi kewirausahaan berhubungan positif dan signifikan terhadap inovasi pada bisnis keluarga. Hasil ini menunjukkan bahwa hipotesis tersebut konsisten dengan penelitian sebelumnya yang dilakukaan oleh (Jalilvand dkk., 2017; Tang dkk., 2015; kalili dkk.,2013; Parkman dkk.,2012) pada penelitian tersebut menunjukkan bahwa orientasi kewirausahaan berhubungan positif dan signifikan terhadap inovasi pada bisnis keluarga.

Hasil penelitian ini sejalan dengan hasil penelitian yang dilakukan oleh (Banker \& sinkula, 2009) Pada penelitian tersebut orientasi kewirausahaan berpengaruh terhadap pembentukan sikap inovasi pada karyawan. Hasil ini sesuai dengan pendapat Zahra dkk. (2006) menyatakan bahwa orientasi kewirausahaan dapat berpengaruh penting terhadap operasional perusahaan dan dapat meningkatkan inovasi guna mengantisipasi perubahan lingkungan bisnis yang semakin ketat. Dengan ini dapat disimpulkan bahwa sikap orientasi kewirausahaan yang terbentuk dapat meningkatkan inovasi didalam perusahaan selain itu dengan adanya orientasi yang kuat maka perusahaan juga akan mampu menghadapi persaingan bisnis yang semakin ketat.

\section{KESIMPULAN}

Berdasarkan hasil analisis dan pembahasan yang telah dilakukan pada bab sebelumnya, maka dapat disimpulkan sebagai berikut:

1. Terdapat hubungan positif dan signifikan antara internal marketing terhadap orientasi kewirauahaan pada bisnis keluarga di Jakarta barat. 
2. Terdapat hubungan positif dan signifikan antara internal marketing terhadap inovasi pada bisnis keluarga di Jakarta barat.

3. Terdapat hubungan positif dan signifikan antara orientasi kewirausahaan terhadap inovasi pada binis keluarga di Jakarta barat.

4. Terdapat hubungan positif orientasi kewirausahaan memediasi internal marketing terhadap inovasi pada bisnis keluarga di Jakarta barat.

Keterbatasan. Pada suatu penelitian tentunya ada keterbatasan, begitupula dengan penelitian ini. penelitian ini mempunyai keterbatasa sebagai berikut:

a. Dalam penelitian ini, semua variabel yang diteliti masih cukup terbatas yaitu hanya ada 1 variabel x, 1 variabel mediasi, dan 1 variabel y. Variabel bebas yang digunakan pada penelitian ini terbatas pada variabel internal marketing.

b. Penelitian yang dilakukan secara singkat dikarenakan keterbatasan waktu dan cangkupan responden yang luas, menyebabkan responden yang dipilih kurang mempresentasikan seluruh pelaku bisnis keluarga yang ada di Indonesia. Selain itu, beberapa kuisioner disebarkan secara online melalui google form, mungkin beberapa responden tersebut tidak mewakili populasi dan sampel pada penelitian ini.

\section{DAFTAR PUSTAKA}

Ahmed, P. K., Rafiq, M. \& Saad, N. M. (2003). Internal marketing and the mediating role of organisational competencies. European Journal of Marketing, 37, pp. 1221-1241.

Aritonang, R. Lerbin. (1998). Penelitian pemasaran-cetakan pertama. Jakarta : UPT Universitas Tarumanagara.

Bagozzi, R. P., \& Yi, Y. (2012). Specification, evaluation, and interpretation of structural equation models.Journal of the Academy of Marketing Science, 40(1), 8-34.

Baker, A. \& Sinkula, S. (2009). The Complementary Effects of Market Orientation and Entrepreneurial Orientation on Profitability in Small Business, Journal of Small Management, 47(4), pp. 443-464.

Chen, Y. C., \& Lin, S. (2013). Applying importance-performance analysis for improving internal marketing ofhospital management in Taiwan.International Business Research, 6(4), 22-45.

Bommer, M. and Jalajas, D., (2002). The innovation work environment of high-technology SMEs in the US and Canada. R\&D Management. 32 (5), 379-386.

Craig, J. B. L., \& Moores, K. (2006). A 10-year longitudinal investigation of strategy, systems, and environment on innovation in family firms.Family Business Review, 19(1), 1-10

Covin, J.G, Green, K.M. and Slevin, D.P., (2006).Strategic Process Effect on The Entrepreneurial Orientation-Sales Growth Rate Relationship, Entrepreneurship Theory and Practice, 30 (1) : 57-81.

ELSamen, A. A., dan M. Alshurideh. (2010). The Impact Of Internal Marketing On Internal Service Quality: A Case Study In a Jordanian Pharmaceutical Company. International Journal Of Business And Management. 7 (19): 84-95. 
Ghozali, Imam. (2014). Structural Equation Modeling Metode Alternatif Dengan Partial Least Squares (PLS). Edisi 4. Semarang: Badan Penerbit Universitas Diponegoro.

Greene, W. E., Walls, G. D \& Schrest, L. J. (1994). Internal marketing: The key to external marketing success. Journal of Services Market. 8: 5-13.

Gronroos, C. (1994). From marketing mix to relationship marketing: towards a paradigm shift in marketing.Management Decision, 32(2), 4-20.

Hotho, S. and Champion, K., (2011). Small businesses in the new creative industries: innovation as a people management challenge. Management Decision. 49 (1), 29 54.

Jalilvand, M. R., Khalilakbar. R., Vosta, L. N., Pool, K. J., Tabaeeian, A. R. (2017). The effect of internal marketing and entrepreneurial orientation on innovation in family businesses: Springer science.

Kajalo, S., \& Lindblom, A. (2015). Market orientation, entrepreneurial orientation and business performance among small retailers. International Journal of Retail \& Distribution Management, 43(7), 580-596.

Kocak, A., Alan, C. \& Sonyel, O. (2016). Market, entrepreneurial, and tecnologi orientations: impact on innovation and firm perfomance, management decision, vol 55 No.2, pp. 248-270.

Madhoushi, M., Sadati, A., \& Delavari, H. (2011). Entrepreneurial Orientation and Innovation Performance: The Mediating Role of Knowledge Management. Asian Journal of Business Management, 3(4), 310-316.

Malhotra, N.K. (2009). Riset Pemasaran, Edisi keempat, Jilid 1, PT Indeks, Jakarta

Miller, Danny. (1983). The Correlates Of Entrepreneurship In Three Types Of Firms. Management Science, 29: 770-791.

Patrick, K. M. and Justin, D. (2010), Entrepreneurial Orientation and Firm Performance: The Unique of innovativeness, Proactiveness, and Risk-taking. Journal of Small Business and Entrepreneurship, 23(1), 39-51.

Piercy, N. F. (1995). Customer satisfaction and the internal market: marketing our customers to our employees. Journal of Marketing Practice: Applied Marketing Science, 1(1), 22-44.

Rafiq, M., \& Ahmed, P. (1993). The scope of internal marketing: defining the boundary between marketing and human resource management. Journal of Marketing Management, 9, 219-232.

Sekaran, U. \& Bougie, R. (2013). Research Methods for Business. United Kingdom: Jhon Wiley \& Sons Ltd.

Sekaran, U. (2006). Research methods for business (terjemahan). Edisi 4.jakarta: salemba empat.

Zahra, S. A., Sapienza, H. J., \& Davidsson, P. (2006), Entrepreneurship and Dynamic Capabilities: A Review, Model and Research Agenda, Journal of Management Studies, 43(4), pp. 917-955.

Zampetakis, L. \& Moustakis, V., (2007). Fostering corporate entrepreneurship through internal marketing. Implications for change in the public sector. European Journal of Innovation Management. 10 (4), 413-43. 